\title{
Adoption of the National Health Insurance Scheme and Its Influence on Organizational Commitment: An Empirical Investigation
}

\author{
Jemeni Chukwudi Unachukwu ${ }^{1}$, Olabode Micheal Oyewole ${ }^{2^{*}}$, Itunu. I. Odebiyi ${ }^{3}$ \\ ${ }^{1}$ Department of Insurance, Federal Polytechnic, Offa, Nigeria \\ ${ }^{2}$ Department of Accountancy, Federal Polytechnic, Offa, Nigeria \\ ${ }^{3}$ Department of Business administration \& Management, Federal Polytechnic, Bida, Nigeria \\ *Corresponding author: oyewoleolabode@yahoo.com
}

DOI: https://doi.org/10.38157/business-perspective-review.v2i3.171

Citation: Unachukwu, J. C., Oyewole, O.M., \& Odebiyi, M. I. I. (2020). Adoption of the National Health Insurance Scheme and Its Influence on Organizational Commitment: An Empirical Investigation. Business Perspective Review 2(3), 1-10. DOI: https://doi.org/10.38157/business-perspective-review.v2i3.171

\section{Research Article}

\section{Abstract}

Purpose: The study examines the influence of the adoption of the National Health Insurance Scheme on organizational commitment with particular reference to Kwara State, Nigeria.

Method: A cross-sectional descriptive study was adopted for the study. A purposive sampling technique was employed to select 350 civil servants from the Ministry of Health in Ilorin. Data were analyzed with the assistance of mean and ordinary least square method of estimation.

Result: The results reveal that the adoption of the National Health Insurance Scheme (NHIS) has a significant influence on organizational commitment. This indicates that the "modus operandi" of the scheme is a strong predictor of organizational commitment in Nigeria.

Implication: Deduction to be made from this result is that the "modus operandi" of the scheme is a strong predictor of organizational commitment. This indicates that the sustainability of the NHIS is a guarantee in the country. This will pave the way to achieve Sustainable Development Goals (SDGs) of 'universal heal th coverage, such as financial risk protection, access to quality essential health care services, and access to safe, effective, quality, and affordable essential medicines and vaccines for all by 2030.

Keywords: NHIS, Organizational Commitment, Diseases, Productivity, Civil Servant.

\section{Introduction}

Today's globalization, cut-throat competitive environment, and growing demand for high quality have led employees in both public and private sectors assuming increased responsibilities and daily job demands in both developed and developing countries. Consequently, this multi-tasking and increase levels of responsibilities affected employees' health and their productivity negatively (Bevan, 2012). Wolf, Feinglass, Thompson, and Baker (2010) lament that employers 
across the globe are currently facing immense challenges as chronic diseases are on the increase such COVID-19 pandemic, heart diseases, hypertension, cancer, diabetes, workers are becoming sicker and less committed and productive due to a global economic crisis, an increasingly fastpaced business environment, growing demands for increased productivity. The report of WHO (2013) also confirms that a high level of multi-tasking and responsibilities have led to increasing levels of sickness absence, and unrealistic time pressures among employees. In another report, the British health insurance provider reaffirms that employees are under tremendous pressure at the workplace as the overall economic environment is unfavorable, and present working conditions have led to increased workloads and demands, and reduced rewards and control (Kuzey, 2018). The problems related to the employees who are facing today's modern organization are stress-related health issues, absenteeism, exploitation, and violence. This development has a substantial effect on organizational commitment and performance.

The study of Edoho, Bamidele, Neji, and Frank (2015) verify that most civil servants are unable to function satisfactorily due to inadequate and poor investment in the fitness and wellness of works, and unsupportive management systems. In the same vein, Akwash (2016) laments that workers are often exposed to poor working conditions, unsatisfactory hygiene environment, and facilities, delay, and denial of promotions, as well as the poor reward system. Therefore, organizations must invest in the fitness and wellbeing of their workers. To support the assertion, Wolf et al (2010) argue that the fitness of employees is a key aspect of worker dedication and performance. Jehu-Appiah, Aryeetey, Agyepong, Spaan, and Baltussen (2012) believe that if fitness and protection are managed at the workplace effectively, organizational commitment and productivity will be enhanced. According to Hughes (2007), health is the protection of the body and the mind of people from illness resulting from work. He also defines safety as the protection of human beings from physical injury. Hughes (2007), also defines health and safety as, the welfare of human beings at work. That is the protection of facilities to preserve the fitness and well-being of individuals at the workplace. Safety hazards according to Cole (2002), are those aspects of the work environment that have the possibility of immediately causing violent damage to an employee while health hazards slowly and cumulatively lead to deterioration of an employee's health.

Having diagnosed the importance of investing in the health and wellbeing of workers, the Nigeria government introduced National Health Insurance Scheme (NHIS) in 2005 to allow its citizens specifically civil servants to have access to first-rate essential health care services and get access to safe, effective, quality, and low-cost imperative drugs and vaccines. According to Akintaro and Adewoyin (2015), health insurance is a legal contract that protects individuals from the financial loss that results from loss of life, lawsuits, loss of health, or loss of property. It offers the ability to cope with some of the risks faced in everyday existence for people and societies. The study by Bloom (2004) and the record of the World Health Organization (2001) confirm that health is one of the primary capabilities that give value to human life; it contributes to each social and financial development. Better health translates into the greater and more equitable distribution of wealth by building human and social capital that increases national productivity (Bloom, 2004; World Health Organization, 2001). 
Based on this background, this contemporary study intends to examine the extent to which the adoption of the National Health Insurance Scheme influences organizational commitment among Nigerian civil servants in Kwara State, Nigeria.

\section{Concept of Health Insurance Scheme in Nigeria}

The introduction of the National Health Insurance Scheme in Nigeria was traced to the National Council of Health meeting held in July 1984 to substitute it with funding health care service (Akintaro \& Adewoyin, 2015). A health insurance plan is the pooling of resources of people or companies to pay for our part of health services in an insurance policy or law. This entails risk sharing by contributions when the illness or injury to be insured is unpredictable and the cost or its occurrence is high, those fortunate enough to be healthy pay for those who are sick, their free will, in turn, be covered by the latter (Akintaro \& Adwoyin, 2015). In 1999, the formal Head of State, General Abdulsalami Abubakar modified the scheme through Decree No. 35 of May 10, 1999, to accommodate more people with the specific objectives such as to control/reduce the arbitrary increase in the value of health services in Nigeria,

to shield households from the excessive cost of medical bills, to make sure equality in the distribution of health care service cost across income groups, and to raise private sector participation in healthcare services in Nigeria (Akintaro \& Adewoyin, 2015; NHIS Decree No. 35 of 1999; Adesina, 2009). Despite the goals of the scheme, we of nonetheless witness poor health care service structures and there are immoderate dependence and pressure on the Federal Government to finance the whole health care delivery.

In 2005, former President Obasanjo similarly modified the scheme at the National Health Conference attended by government representatives, international businesses, and other key stakeholders in the health care sector. The operational guiding principle of the National Health Insurance Scheme was once launched in October 2005 which is in line with the precedence objectives of the United Nations Sustainable Development Goals (UNSDG) on reaching 'universal health coverage, such as economic risk protection, access to nice indispensable health care services, and access to safe, effective, quality, and lower-priced indispensable medicines and vaccines for all (Uzobo1 \& Ayinmoro, 2019; Adewole, Dairo \& Bolarinwa, 2016; Olanrewaju, Ajileye, Asekun-Olarinmoye, Adeoye, Oyerinde, \& Adebola, 2019). The modification of the National Health scheme is aimed at providing access to good health care services for both federal and state employees' including their spouse and four biological children to have access to good healthcare services and benefit from social health insurance programs (Uzobo1 \& Ayinmoro, 2019). The scheme specified that both the government and employees will be registered and they expect to contribute $15 \%$ to the scheme, the government/employer is expected to pay $10 \%$, while the employee is also expected to pay $5 \%$ of basic salary to enjoy healthcare benefit. However, civil servants are not cozy with the scheme due to insufficient legal framework for the scheme, poor government funding and implementation of the Act, and lack of political will. The depictions of Abdulraheem, Olapipo, and Amodu (2012), and Abimbola, Okoli, Olubajo, Abdullahi, and Pate (2012) agree with the above statement that the high-quality of health care services delivered is 
poor and remains a huge source of concern to civil servants in the country. This development scenario has a negative influence on workers' attitudes to work.

\section{Concept of Organizational Commitment}

Organizational commitment has a necessary location in the study of organizational behavior. This is in part due to the substantial wide variety of work that has discovered relationships between organizational commitment and attitudes and behaviors in the place of work (Akintayo, 2010; Adekola, 2012). Furthermore, Arnold (2005) states that the reasons for studying organizational commitment are related to (a) employee behaviors and performance effectiveness, (b) attitudinal, affective, and cognitive constructs such as job satisfaction, (c) traits of the employee's job and roles, such as accountability and (d) private characteristics of the worker such as age, job tenure. Organizational commitment has been studied in the public, private, and non-profit sectors, and more recently internationally. Early studies (Cohen, 2003; Miller \& Lee, 2001) focused on defining the concept and current research (Akintayo 2010; Adekola, 2012; Adeniji 2012) continues to look at organizational dedication through two popular approaches: commitment-related attitudes and commitment-related behaviors. A range of antecedents and outcomes has been recognized in the past thirty years (Miller, 2003; Arnold, 2005). Many researchers have suggested that employee engagement is multidimensional thinking (Miller \& Lee, 2001) with cognitive (or rational), emotional (or affective), and behavioral components (Kipkebut, 2010). The Towers Perrin Talent Report proved the definition of worker engagement that consists of both emotional and rational variables. According to the report, "the emotional factors tie to people's personal satisfaction and sense of inspiration and affirmation they get from their work and from being part of their organization.

\section{Empirical Review}

The following previous researches are reviewed. For example, Uzobo and Ayinmoro (2019) conduct a study on the level of satisfaction and health effects of the National Health Insurance Scheme (NHIS) among federal civil servants in Bayelsa State, Nigeria. They find out that a positive strong correlation exists between NHIS and service satisfaction. In another study, Olanrewaju, Ajileye, Asekun- Olarinmoye, Adeoye, Oyerinde, and Adebola (2019) assess the awareness, attitude, and perception of enrolees towards the uptake of state health insurance scheme in Lokoja, Kogi state. They discover that there is a low level of awareness regarding health insurance schemes among the civil servants and artisans in Kogi State. Ekwuluo, Eluwa, Okereke, and Orji (2018) also carry out a study on the determination of knowledge, attitudes to, and utilization of the National Health Insurance Scheme (NHIS) among health workers in Enugu State, Nigeria. The study reveals a high awareness of the National Health Insurance Scheme but utilization of, and attitudes to the National Health Insurance Scheme are not encouraging. Ilochonwu and Adedigba (2017) also assess the awareness, utilization, and perception of healthcare workers towards the National Health Insurance Scheme in a tertiary hospital, Ile-Ife. The finding establishes that the awareness of the scheme is fair and the perception was good but utilization was not very encouraging. In the same vein, Gbadamosi and Famutimi (2017) assess 
the perception and satisfaction of employees with the National Health Insurance Scheme (NHIS) Services and to ensure quality NHIS services for all employees in health institutions in Nigeria. The findings show that satisfaction with NHIS services was low at UCH, Ibadan, Nigeria and this may result in under-utilization of the scheme, poor health status, and low productivity among the employees of the institution. Olayemi (2017) also assesses awareness and perception of the National Health Insurance Scheme (NHIS) among the librarians. The findings of the study indicate a high level of awareness of the scheme among librarians in Nigeria.

Similarly, Obembe, Abodunrin, and Jegede (2017) also determine enrollees' satisfaction with Health Maintenance Organizations (HMOs) services and the willingness of the non-insured to participate in the health insurance schemes in Abuja. The study revealed that the level of satisfaction of enrollees with the services rendered by HMOs is very low. The study of Adewole, Dairo, and Bolarinwa (2016) use logistic regression analysis to assess the level of coverage of the NHIS among the formal sector workers in Nigeria. The study establishes that majority of the respondents aware of the scheme but few of them pay for health care services through the NHIS. In another study, Ukamaka (2016) also assesses the knowledge, attitude, perception, and practice of the health insurance scheme among community Pharmacists in Lagos State. The study shows that level of knowledge of the scheme, attitude, and perception toward the scheme is very poor. Akintaro and Adewoyin (2015) also conduct a study on the knowledge and attitude towards the National Health Insurance Scheme in Nigerian research institutes. They find out that the level of awareness is very low. In the same vein, Okaro, Ohagwu, and Njoku (2010) also assess the knowledge and attitude towards the NHI scheme among radiographers in South East, Nigeria. They also find out that the level of awareness is very high among the radiographers.

\section{Gap in the Literature}

All the available studies in Nigeria such as Uzobo and Ayinmoro (2019), Olanrewaju et al (2019), Ekwuluo et al (2018), Ilochonwu and Adedigba (2017), Gbadamosi and Famutimi (2017), Olayemi (2017), Obembe, Abodunrin and Jegede (2017), Adewole, Dairo and Bolarinwa (2016), Ukamaka (2016), Akintaro and Adewoyin (2015) and Okaro, Ohagwu and Njoku (2010) focus on the knowledge, awareness, and utilization of the scheme, and perception of workers towards the scheme. To the best of the researchers' knowledge, no available study examines how the extent of adoption of the National Health Insurance Scheme influences organizational commitment among Nigerian Civil Servants.

\section{Methodology}

A cross-sectional descriptive research design was adopted for the study. A purposive sampling technique was employed to select 350 civil servants from the Ministry of Health in Ilorin, Kwara State. The choice of this ministry is based on the fact that is prone to COVID-19 pandemic in the state. A structured questionnaire was used to collect data from the respondents in the study area. The scales for the study consist of the HNIS Scale and Organizational Commitment Scale. These scales were developed and validated by Okaro, Ohagwu, and Njoku (2010) and Allen and Meyer (1990). They are 5-point Likert-type rating scales ranging from strongly agree (5) to strongly 
disagree (1) and the reliability and validity of scales were determined (see Table 1). Data were analyzed with the assistance of mean and ordinary least square method of estimation.

Table 1: Measurement of instruments

\begin{tabular}{|c|c|c|c|c|c|c|}
\hline Construct & Items & $\begin{array}{l}\text { Meaning } \\
\text { Bartlett }\end{array}$ & $\mathrm{KMO}$ & $\begin{array}{l}\text { Eigenvalue } \\
\text { of the } \\
\text { principal } \\
\text { Component }\end{array}$ & $\begin{array}{l}\% \text { of the } \\
\text { variance }\end{array}$ & $\begin{array}{c}\text { Cronbach's } \\
\alpha\end{array}$ \\
\hline NHIS Scale. & 8 & $\begin{array}{c}\mathrm{p}=.000 \\
\text { (significant) }\end{array}$ & 0.821 & 3.098 & $70.71 \%$ & 0.81 \\
\hline $\begin{array}{c}\text { Organizational } \\
\text { Commitment Scale }\end{array}$ & 9 & $\begin{array}{c}\mathrm{p}=.000 \\
\text { (significant) }\end{array}$ & 0.801 & 2.992 & $71.01 \%$ & 0.78 \\
\hline
\end{tabular}

Source; Data Analysis

\section{Results and Discussion}

Table 2: Mean Response Score on National Health Insurance Scheme

\begin{tabular}{|c|c|c|c|}
\hline Statement & $\mathrm{N}$ & Mean & Rank \\
\hline $\begin{array}{l}\text { The national health insurance scheme enables me to access } \\
\text { to quality essential health care services }\end{array}$ & 350 & 3.61 & $4^{\text {th }}$ \\
\hline $\begin{array}{l}\text { I have registered under the scheme because I need health } \\
\text { insurance }\end{array}$ & 350 & 3.98 & $2^{\text {nd }}$ \\
\hline There is the feasibility of sustenance of NHIS in Nigeria & 350 & 3.08 & $7^{\text {th }}$ \\
\hline The continuation of the scheme is paramount to me. & 350 & 3.51 & $5^{\text {th }}$ \\
\hline $\begin{array}{l}\text { I had an adequate understanding of the national health } \\
\text { insurance scheme and its benefits }\end{array}$ & 350 & 4.21 & $1^{\text {st }}$ \\
\hline $\begin{array}{l}\text { The national health insurance scheme enables me to have } \\
\text { access to affordable essential medicines and vaccines. }\end{array}$ & 350 & 3.12 & $6^{\text {th }}$ \\
\hline $\begin{array}{l}\text { My employer remits my income into the scheme as when } \\
\text { due. }\end{array}$ & 350 & 3.05 & $8^{\text {th }}$ \\
\hline $\begin{array}{l}\text { The national health insurance guarantees financial risk } \\
\text { protection. }\end{array}$ & 350 & 3.71 & $3^{\text {rd }}$ \\
\hline Grand Mean & & 3.53 & \\
\hline
\end{tabular}

Source; Field Survey

Table 2 summarizes the responses of the perception of the participants on the National Health Insurance Scheme (NHIS). The grand mean of 3.53, which is above criterion mean 3 indicates that the scheme is effective and efficient in the state. The results further reveal that majority of the participants adequately understand the benefits of the scheme and key into the program, because they believe that the scheme guarantees their financial risk protection and enable them to access to quality essential health care services. This study concurs with the finding of Uzobo and Ayinmoro (2019) that a positive strong correlation exists between NHIS and service satisfaction. This development is in line with the priority targets of the United Nations Sustainable Development Goals (UNSDG) on achieving 'universal health coverage, including financial risk 
protection, access to quality essential health care services, and access to safe, effective, quality, and affordable essential medicines and vaccines for all by 2030.

\section{Table 3: Mean Response Score on Organizational Commitment}

\begin{tabular}{|cccc|}
\hline Statement & $\mathrm{N}$ & Mean & Rank \\
\hline $\begin{array}{c}\text { I find that the job I am doing is meaning to the government } \\
\text { In my position, I have the opportunity to learn and grow } \\
\text { within the ministry. }\end{array}$ & 350 & 4.78 & $6^{\text {th }}$ \\
\hline I tell my friends about the great ministry I work for & 350 & 3.45 & $1^{\text {st }}$ \\
\hline I am proud to say that I work for this ministry & 350 & 398 & $4^{\text {th }}$ \\
\hline I feel that my work is appreciated within the ministry & 350 & 3.92 & $5^{\text {th }}$ \\
\hline I find it difficult to detach myself from work & 350 & 4.05 & $2^{\text {nd }}$ \\
\hline I feel absorbed in my work situation & 350 & 3.91 & $6^{\text {th }}$ \\
\hline Accomplishments in my work make me happy & 350 & 4.02 & $3^{\text {rd }}$ \\
\hline I regularly receive praise or recognition for a job well done & 350 & 3.69 & $8^{\text {th }}$ \\
\hline Grand Mean & & & 3.87 \\
\hline
\end{tabular}

Source; Field Survey

Table 3 summarizes the level of organizational commitment among the participants. The grand mean of 3.87, which is above criterion mean 3 indicates that the level of organizational commitment of civil servants is high and encouraging. The results further reveal that majority of the participants agree that they have the opportunity to learn and grow within the Ministry, they find it difficult to detach themselves from work, accomplishments in their work, make them happy, and they also proud to say that they work for their Ministry, with mean values of 4.07, $4.05,4.02$, and 3.98 respectively.

Table 4 reveals the influence of the National Health Insurance Scheme adoption on Organizational commitment. The F-value of 3.896 and $\mathrm{t}$-value of 1.974 indicates that the adoption of NHIS has a significant influence on organizational commitment. The $\beta$-value of 0.364 indicates that the adoption of NHIS contributes 36.4 to organizational commitment. Deduction to be made from this result is that the "modus operandi" of the scheme is a strong predictor of organizational commitment. This finding implies that the sustainability of the scheme is a guarantee in the country. 
Table 4: Regression result of Influence of National Health Insurance Scheme adoption on Organizational commitment

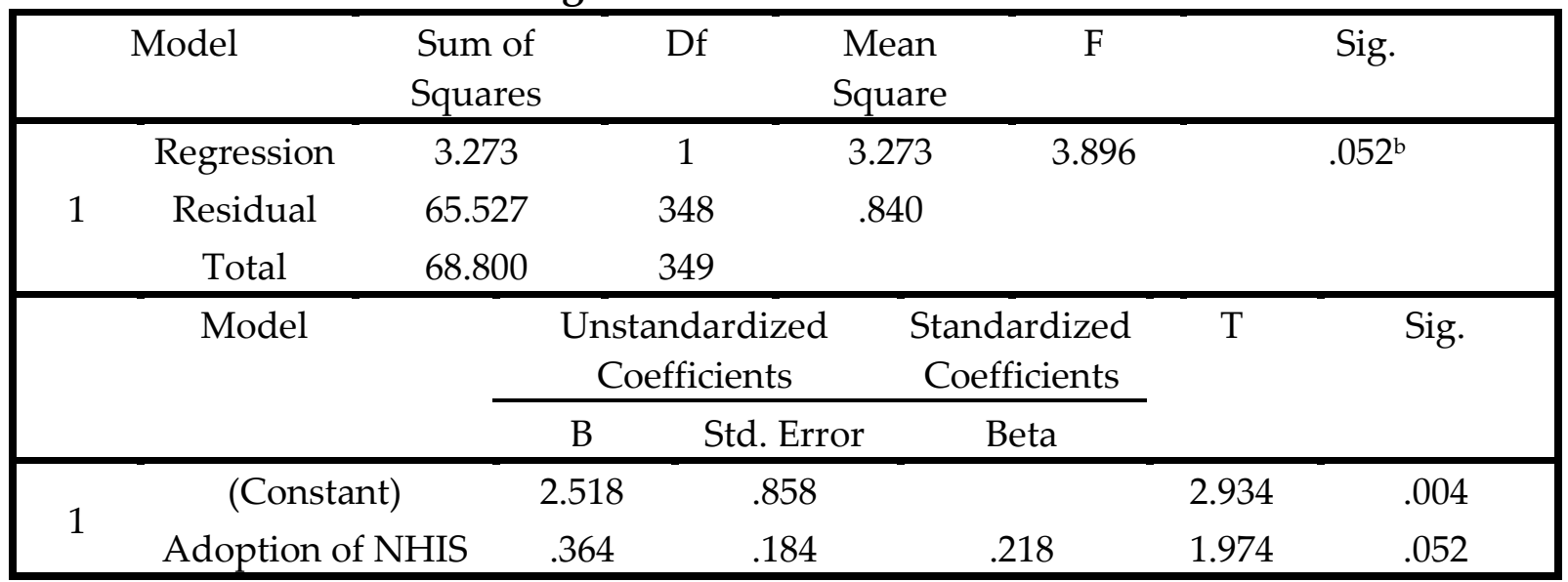

a. Dependent Variable: Organizational Commitment

\section{Conclusion and Recommendations}

The study examines the influence of the adoption of the National Health Insurance scheme on organizational commitment with particular reference to Kwara State, Nigeria. A cross-sectional descriptive research design was adopted for the study. Purposive sampling technique was employed to select 350 civil servants from the Ministry of Health in Ilorin, Data were analyzed with the assistance of mean and ordinary least square method of estimation. The results reveal that the adoption of NHIS has a significant influence on organizational commitment. This indicates that the "modus operandi" of the scheme is a strong predictor of organizational commitment in Nigeria.

Therefore, the study recommends that government and non-governmental organizations should fund the health sector and the NHI scheme should be extended to private organizations, and every individual in the country. This will go a long way to achieve SDGs of 'universal health coverage', including financial risk protection, access to quality essential health care services, and access to safe, effective, quality, and affordable essential medicines and vaccines for all by 2030.

Authors' contributions: All the three authors jointly contributed to the data collection, data analysis, and writing of the manuscript.

Conflicts of Interest: The authors declare no conflict of interest.

\section{REFERENCES}

Abdulraheem, I. S, Olapipo, A. R., \& Amodu M O (2012). Primary health care services in Nigeria: critical issues and strategies for enhancing the use by the rural communities, Journal of Public Health and Epidemiology; 4:5-13.

Abimbola, S, Okoli, U, Olubajo, O, Abdullahi, M. J., \&Pate, M. A. (2012). The Midwives Service Scheme in Nigeria. PLoS Med 2012; 9(5): e1001211. doi:10.1371/journal.pmed.1001211.

Adekola, B. (2012). The Impact of Organizational Commitment on Job Satisfaction: A of Employee at Nigerian Universities. International Journal of Human Resources Studies, 2(2), 20-29. 
Adeniji, A. A. (2011). Organizational Climate and Job Satisfaction among Academic Staff in Some Selected Private Universities in Southwest Nigeria. (Unpublished Ph.D. Thesis) of Covenant University, Ota, Ogun State, Nigeria.

Adewole D. A, Dairo M. D, \& Bolarinwa, O. A. (2016). Awareness and Coverage of the National Health Insurance Scheme among Formal Sector Workers in Ilorin, Nigeria. Afr. J. Biomed. Res. Vol.19; 1-10.

Akintaro, O.A., \& Adwoyin, O.O. (2015). Knowledge and Attitude towards National Health Insurance Scheme in Nigerian Research Institutes. Huria Journal. 20, 81-90.

Akintayo, D. I. (2010). Work-Family Role Conflict and Organizational Commitment among Industrial Workers in Nigeria. Journal of Psychology and Counseling, 2(1), 1-8.

Akwash, B.A. F. (2016). Appraising Nutrition and Child Rearing as an Antidote to Psychological Well-Being and Child Development in Nigeria. IJRDO - Journal of Social Science and Humanities Research (ISSN: 2456-2971). 1, $5 ; 26-45$.

Allen, N. J., \& Meyer, J. P. (1990). The measurement and antecedents of affective, continuance, and normative commitment to the organization. Journal of occupational psychology, 63(1), 1-18.

Arnolds, C.A. (2005). The Management of the Early Stages of Restructuring in a Tertiary Education Institution: An Organizational Commitment Perspective. South African Journal of Business Management, 35(2), 1-13.

Bevan, S. (2012). Good work, High performance, and productivity. The paper prepared for the European HRD Forum, Lisbon, (2012).

Bloom, G. (2004). China in transition: Challenges to urban health services. In Transition in urban China by Bloom G. and Tang S.H. (ed), Ashgate Publishing Limited, England, 127-142.

Cohen, A. (2003). Career Stage as a Moderator of the Relationships between Organizational Commitment and Its Outcomes: A Meta-Analysis. Journal of Occupational Psychology, 64(3), 253-268.

Cole, G.A. (2002).Personnel and Human Resource Management. 5th Edition. Continuum Publisher, London.

Edoho, S. A. P., Bamidele, E., Neji, O. I., \& Frank, A. E. (2015). Job Satisfaction among Nurses in Public Hospitals in Calabar, Cross River State Nigeria. American Journal of Nursing, 4(4), 231-237

Ekwuluo, C. E, Eluwa, A. N, Okereke I. C., \& Orji, S. B. (2018). Knowledge, Attitudes to, and Utilization of The National Health Insurance Scheme (NHIS) Among Health Workers In The University of Nigeria Teaching Hospital(UNTH), Ituku-Ozalla, Enugu State, Nigeria. International Journal of Research - Granthaalayah, 6(1), 122. https://doi.org/10.5281/zenodo.1162015.

Gbadamosi, I.A.,\& Famutimi, E.O. (2017). Perception and Satisfaction of Employees with National Health Insurance Scheme Services: A Descriptive Study at University College Hospital, Ibadan, Nigeria. International Journal of Tropical Disease\& Health. 22(1): 1-12.

Hughes, B. M. (2007). Social support in ordinary life and laboratory measures of cardiovascular reactivity: Gender differences in habituation-sensitization. Annals of Behavioral Medicine, 34, 166-176.

Ilochonwu, N.A., \& Adedigba, M.A. (2017). Awareness and utilization of national health insurance schemes by healthcare workers in southwest Nigeria. African Journal of Oral Health; 25-34.

Jehu-Appiah, C., Aryeetey, G., Agyepong, I., Spaan, E., \& Baltussen, R., (2012).Household perceptions and their implications for enrolment in the National Health Insurance Scheme in Ghana. Health Policy and Planning, 27, 222-233.

Kipkebut, D. J. (2010). Organisational Commitment and Job Satisfaction in Higher Educational Institutions: The Kenyan Case, (UnpublishedPhD Thesis). Middlesex University.

Kuzey, C, (2018). Impact of Health Care Employees' Job Satisfaction on organizational Performance Support Vector Machine Approach. Journal of Economics and Financial Analysis, 2(1); 45-68.

Miller, A. (2003). Mentoring Students and Young People: A Handbook of Effective Practice. London: Kogan Page.

Miller, D., \& Lee, J. (2001). The People Make the Process: Commitment to Employees, Decision- Making and Performance. Journal of Management, 27, 163-189.

Obembe, O.O, Abodunrin, O.L., \& Jegede, S.O. (2017). Health insurance enrollees' satisfaction with health maintenance organizations and non-enrollees' willingness to participate and pay for health insurance in Abuja, Nigeria. International Journal of Community Medicine and Public Health; 4(11):3976-3982

Obikeze, E, Onwujekwe, O, Uzochukwu, B, Chukwuogo, O, Uchegbu, E, \&Soludo, E. (2013). Benefit Incidence of National Health Insurance Scheme in Enugu State, South-East Nigeria. Afr J Health Econ. 2013; 2(1):13-29. 
Okaro, A.O, Ohagwu, C.C, \& Njoku, J. (2010). Awareness and Perception of National Health Insurance Scheme among Radiographers in SouthEast Nigeria. American Journal of Scientific Research, 2010; 8: 21.

Olanrewaju, M.F, Ajileye, D.O, Asekun-Olarinmoye, T.F, Adeoye, A.O, Oyerinde, O.O \& Adebola, O. (2019). Awareness, Attitude, and Perception of Enrolees towards the Uptake of State Health Insurance Scheme in Lokoja, Kogi State, Nigeria. International Journal of Engineering Science Invention. 8(10); 14-20.

Olayemi, O.M. (2017). Awareness and Perception of National Health Insurance Scheme (NHIS) among Librarians in Nigeria. International Journal of Perceptions in Public Health, 2(1):56-63

Ukamaka, G.O. (2016). Assessment of Knowledge Attitude Perception and Practice of Health Insurance Scheme among Community Pharmacies in Lagos State. Texila International Journal of Public Health.4 (4); 1-10.

Uzobo, E., \& Ayinmoro, A. D. (2019). Health effects of the National Health Insurance Scheme (NHIS): A study among federal civil servants in Bayelsa State, Nigeria. Journal of Health and Social Sciences. 4(2); 265-276.

Wolf, M. S., Feinglass J., Thompson J., \& Baker D. W. (2010). In search of "low health literacy": Threshold vs. gradient effect of literacy on health status and mortality. Social Science $\mathcal{E}$ Medicine, 70, 1335-1341. doi:10.1016/j.socscimed.2009.12.013.

World Health Organization. (2001). Maternal mortality in 1995: Estimates developed by WHO. Geneva: WHO.

WHO (2013). The World Health Report 2013. Research for universal health coverage. 1st ed. Luxembourg: World Health Organisation; 2013.

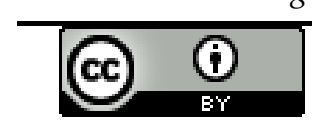

(C) 2020 by the authors. Licensee Research $\mathcal{E}$ Innovation Initiative, Michigan, USA. This article is an open-access article distributed under the terms and conditions of the Creative Commons Attribution (CC BY) license (http://creativecommons.org/licenses/by/4.0/). 